\title{
Re-assembly of nineteenth-century smallpox vaccine genomes reveals the contemporaneous use of horsepox and horsepox-related viruses in the USA
}

\author{
Annika Brinkmann ${ }^{1}$, Aline R. V. Souza ${ }^{2}$, José Esparza ${ }^{3}$, Andreas Nitsche ${ }^{1}$ and Clarissa R. Damaso ${ }^{2 *}$ (D)
}

This comment refers to the article available at https://doi.org/10.1186/ s13059-020-02203-z.

* Correspondence: damasoc@biof. ufrj.br

${ }^{2}$ Instituto de Biofísica Carlos Chagas Filho, Universidade Federal do Rio de Janeiro, Av. Carlos Chagas Filho, 373 - CCS, Ilha do Fundão, Rio de Janeiro, RJ 21941-590, Brazil

Full list of author information is available at the end of the article

\begin{abstract}
According to a recent article published in Genome Biology, Duggan and coworkers sequenced and partially assembled five genomes of smallpox vaccines from the nineteenth century. No information regarding the ends of genomes was presented, and they are important to understand the evolutionary relationship of the different smallpox vaccine genomes during the centuries. We re-assembled the genomes, which include the largest genomes in the vaccinia lineage and one true horsepox strain. Moreover, the assemblies reveal a diverse genetic structure in the genome ends. Our data emphasize the concurrent use of horsepox and horsepox-related viruses as the smallpox vaccine in the nineteenth century.
\end{abstract}

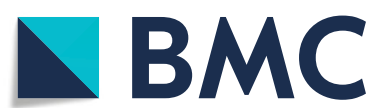

(c) The Author(s). 2020 Open Access This article is licensed under a Creative Commons Attribution 40 International License, which permits use, sharing, adaptation, distribution and reproduction in any medium or format, as long as you give appropriate credit to the original author(s) and the source, provide a link to the Creative Commons licence, and indicate if changes were made. The images or other third party material in this article are included in the article's Creative Commons licence, unless indicated otherwise in a credit line to the material. If material is not included in the article's Creative Commons licence and your intended use is not permitted by statutory regulation or exceeds the permitted use, you will need to obtain permission directly from the copyright holder. To view a copy of this licence, visit http://creativecommons.org/licenses/by/4.0/. The Creative Commons Public Domain Dedication waiver (http://creativecommons.org/publicdomain/zero/1.0/) applies to the data made available in this article, unless otherwise stated in a credit line to the data. 
In a recent Genome Biology article, Duggan and colleagues described the partial genomic sequences of five American smallpox vaccines from the mid to late nineteenth century [7]. Phylogenetic analyses revealed that the viruses are closely related to HSPV and to the Mulford 1902 strain. However, the only genome assembled de novo (VK1) has 184,677 bp and lacks nearly 20,000 bp of the left end. Because the right end is complete, we hypothesized that reads covering the left end should also be available.

Therefore, FastQ files were downloaded from Sequence Read Archive (PRJNA561155) and trimmed (Trimmomatic-v0.39, Phred-33 quality score) [8]. Full genomes were assembled by an iterative workflow: de novo assembly of adapterremoved reads by using Spades v3.13.1 (Phred offset-33, standard parameters) [9], mapping of the trimmed reads to the contigs to increase contig size, visual screening for accuracy, and correction of mis-assembled regions with Geneious Prime

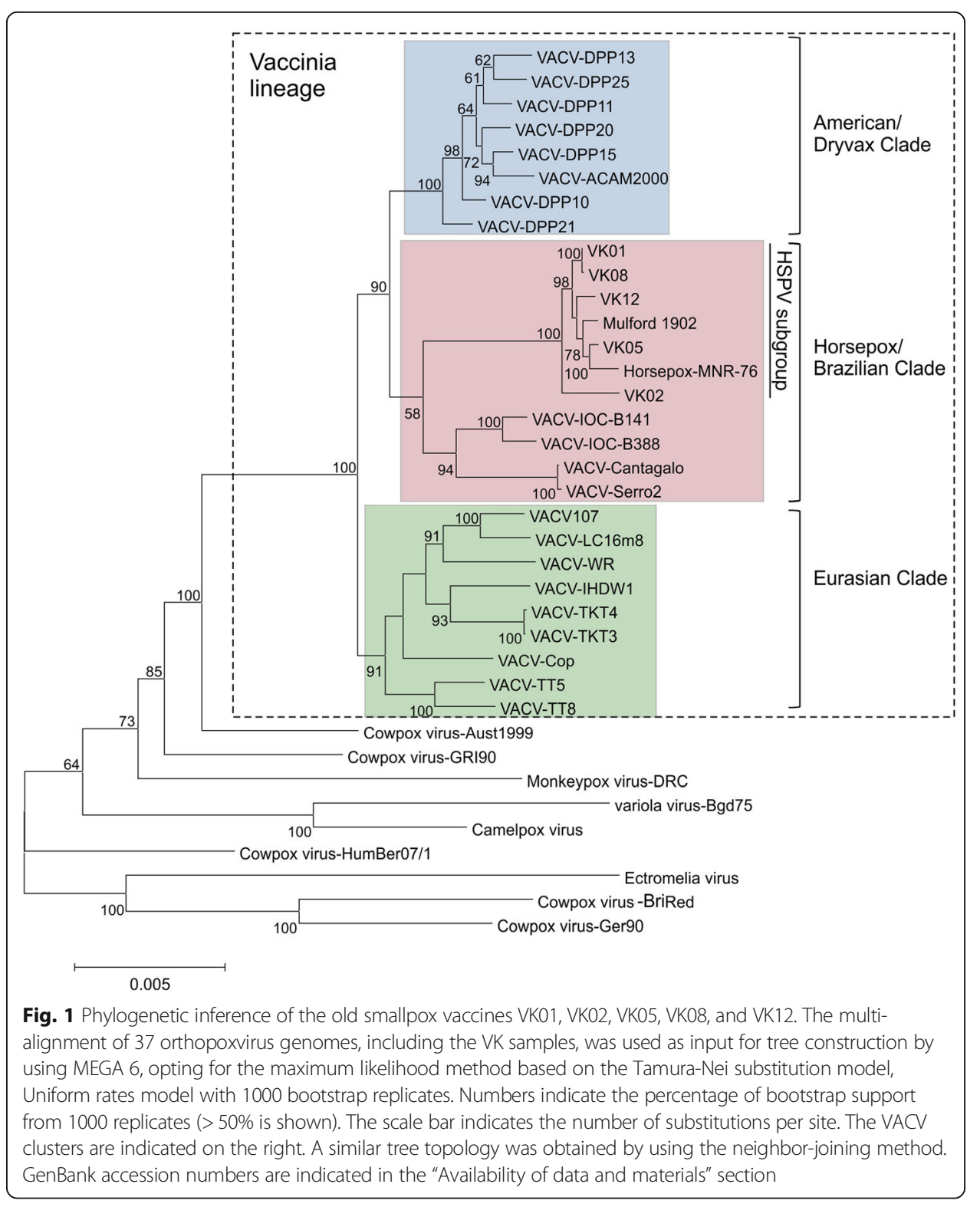


2020.0.5. The final genomes were validated for accuracy by mapping with all reads and screened for inconsistency in the continuous assembly. Inverted terminal repeat (ITR) regions were identified with Geneious Prime Repeat Finder. Genomes were annotated by using Genome Annotation Transfer Utility (GATU) [10] and CLC Main Workbench v8.0, followed by visual screening [4, 6]. Orthopoxvirus sequences were aligned by using Mafft Server v7 [11] and used for phylogenetic inference by using Mega v6 [12].

All five re-assembled genomes are phylogenetically clustered within the HSPV subgroup of the VACV lineage (Fig. 1), confirming the findings of Duggan and colleagues [7]. However, our data provides important genetic information that was not revealed by the published assembly. We observed genomes of different sizes and number of ORFs and, interestingly, with distinct structures in the left and right ends. Table 1 summarizes our findings and Fig. 2 shows the genome structure of the left and right ends of the VK genomes. VK01 and VK12 have the largest genomes in the VACV lineage with $214,388 \mathrm{bp}$ and $219,647 \mathrm{bp}$ (Table 1), respectively, mainly due to the presence of unique insertions of $14.2 \mathrm{~kb}$ and $15.8 \mathrm{~kb}$ in the left end, probably resulting from a non-tandem duplication of an equivalent region in the right end of the genome and the insertion of cowpox gene orthologs (Fig. 2a, insert).

Interestingly, the $10.7-\mathrm{kb}$ and the $5.5-\mathrm{kb}$ deletions found, respectively, in the left and right ends of the genomes of all VACV strains [5] as well as in the Mulford 1902 strain [4] are also found partially or completely in the VK01 and VK8

Table 1 Genomic features of the re-assembled genomes of VK01, VK02, VK05, VK08, and VK12 vaccines

\begin{tabular}{|c|c|c|c|c|c|c|c|c|}
\hline \multirow[t]{2}{*}{$\begin{array}{l}\text { Sample } \\
\text { a (year) }\end{array}$} & & \multirow[t]{2}{*}{$\begin{array}{l}\text { Genome } \\
\text { size (bp) }\end{array}$} & \multirow{2}{*}{$\begin{array}{l}\text { ITR } \\
\text { size } \\
\text { (bp) }\end{array}$} & \multirow[t]{2}{*}{$\begin{array}{l}\text { ORFs } \\
\text { (no.) }\end{array}$} & \multirow{2}{*}{$\begin{array}{l}\text { Genome } \\
\text { coverage } \\
\text { (fold) }\end{array}$} & \multicolumn{2}{|c|}{$\begin{array}{l}\text { \% identity } \\
\text { HSPV MNR-76 }\end{array}$} & \multirow{2}{*}{$\begin{array}{l}\text { 'Presence of } \\
\text { the deletions } \\
\text { in the } \\
\text { genome's left } \\
\text { and right } \\
\text { ends } \\
\text { characteristic } \\
\text { of all VACV } \\
\text { strains but } \\
\text { absent in } \\
\text { HSPV }\end{array}$} \\
\hline & & & & & & $\begin{array}{l}\text { Whole } \\
\text { genome }\end{array}$ & $\begin{array}{l}{ }^{b} \text { Conserved } \\
\text { core region }\end{array}$ & \\
\hline \multirow{2}{*}{$\begin{array}{l}\text { Horsepox-related } \\
\text { virus with VACV-like } \\
\text { genome ends }\end{array}$} & $\begin{array}{l}\text { VK01 } \\
(1866)\end{array}$ & 214,388 & $\begin{array}{l}22, \\
960\end{array}$ & 248 & 1762 & 0.903 & 0.997 & Yes \\
\hline & $\begin{array}{l}\text { VK08 } \\
(1873)\end{array}$ & 204,481 & 9070 & 240 & 746 & 0.943 & 0.997 & Yes \\
\hline \multirow[t]{2}{*}{$\begin{array}{l}\text { Horsepox-related } \\
\text { virus with one } \\
\text { genome end } \\
\text { similar to VACV }\end{array}$} & VK02 (ND) & 199,509 & 616 & 236 & 662 & 0.889 & 0.995 & $\begin{array}{l}\text { Deletion in } \\
\text { the left end } \\
\text { only }\end{array}$ \\
\hline & $\begin{array}{l}\text { VK12 } \\
(1859)\end{array}$ & 219,647 & $\begin{array}{l}23 \\
165\end{array}$ & 253 & 937 & 0.856 & 0.997 & $\begin{array}{l}\text { Deletion in } \\
\text { the right end } \\
\text { only }\end{array}$ \\
\hline \multirow[t]{2}{*}{ Horsepox virus } & VK05 (ND) & 212,688 & 6935 & 236 & 946 & 0.997 & 0.998 & No \\
\hline & $\begin{array}{l}\text { dHSPV } \\
\text { MNR-76 }\end{array}$ & 212,633 & 7527 & 236 & ND & 1 & 1 & No \\
\hline
\end{tabular}

${ }^{a}$ Years according to Duggan et al. [7]. ND means not determined

${ }^{b}$ The conserved core region refers to approximately 99.0000 bp spanning from genes F9L to A24R

'The deletions correspond to $10.7 \mathrm{~kb}$ and $5.5 \mathrm{~kb}$ stretches of DNA present in HSPV-MR76, but absent in all VACV strains and in the Mulford $1902[4,5]$

${ }^{d}$ Horsepox virus strain MNR-76 was included for the sake of comparison [5]. GenBank accession numbers are indicated in the "Availability of data and materials" section 


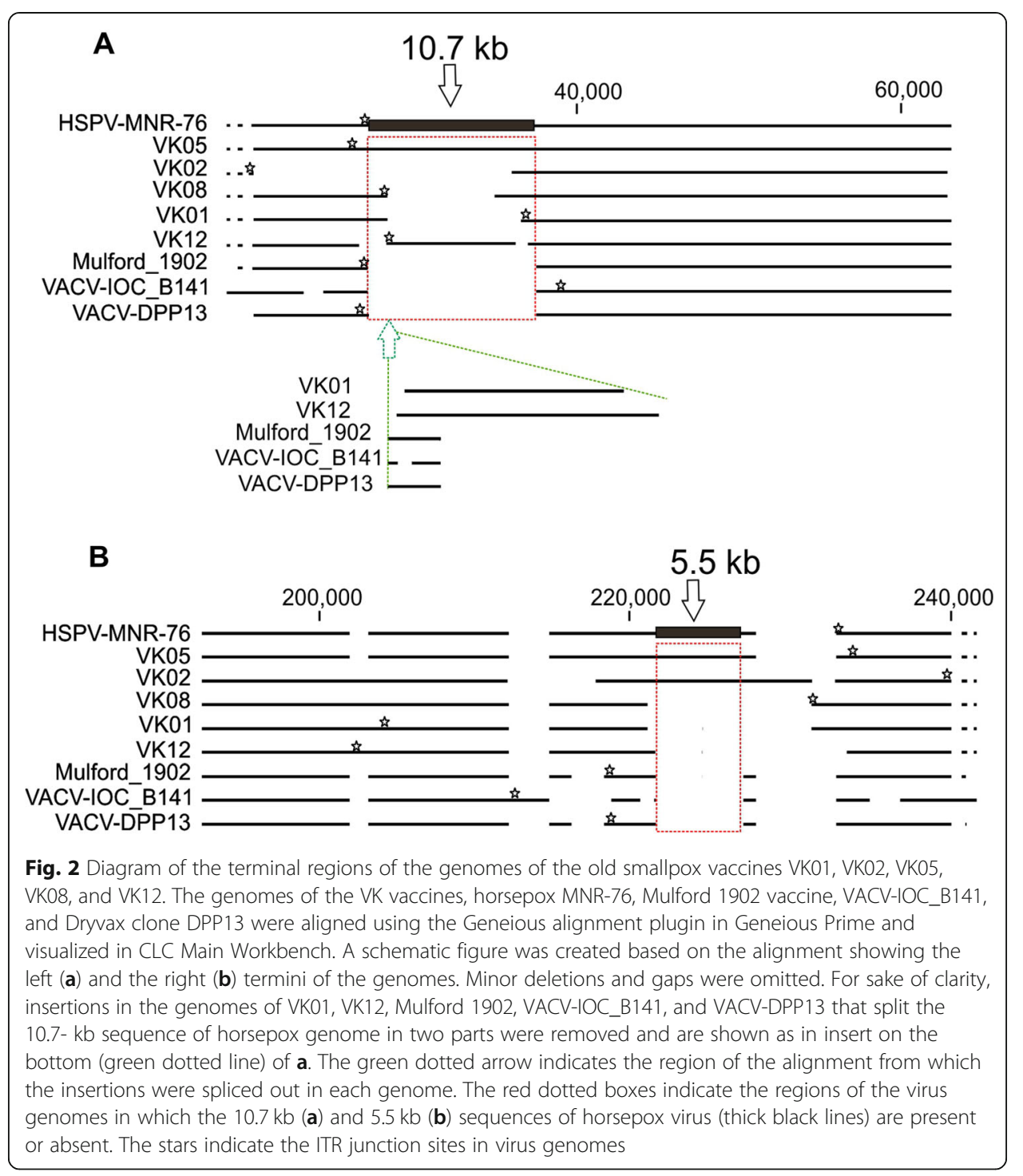

genomes in the left and right ends, respectively. However, those deletions are not found in VK5, VK12 (only the right deletion is found), and VK2 (only the left deletion is found). In fact, the VK05 genome has the same genome structure (Fig. 2) and the highest identity to HSPV-MNR-76 across the whole genome, representing a true HSPV strain (Table 1). So far, MNR-76, isolated from Mongolian horses in 1976, and MNR, a synthetic recombinant horsepox virus, are the only extant strains of HSPV $[5,13]$.

VK08 genome is very similar to VK01, except for the absence of the 14.2-kb insertion (Fig. 2a, insert). VK02 genome has a 15-kb deletion near the very left end of the genome (Fig. 2a), resulting in the shortest ITRs in the VACV lineage (Table 1).

In conclusion, the re-assembly of the five VK genomes exposes the complex genetic diversity of the old smallpox vaccine genomes. We present evidence of the contemporaneous use of HSPV and HSPV-related viruses as the smallpox vaccine 
in the nineteenth century. The results also reveal that HSPV-related vaccines had been used in the USA at least 36 years before the Mulford 1902 strain. In the nineteenth century, vaccine seeds were constantly imported from Europe for smallpox vaccine production in the USA. Therefore, it is likely that HSPV and HSPV-related viruses were repeatedly introduced in the USA at that time and that similar vaccines were also manufactured and used in Europe in the nineteenth century [14].

\section{Acknowledgements}

We thank Ursula Erikli for copyediting and Victor S Ferreira for developing an algorithm to automate formatting of annotation files.

\section{Authors' contributions}

CRD conceived the present idea. CRD, JE, and AN wrote the manuscript with input and edits from all authors. $A B$ and ARVS conducted the bioinformatics analyses. All authors read and approved the final manuscript.

\section{Funding}

This work was partially supported by a grant from the Bill \& Melinda Gates Foundation (INV-009850, formerly OPP1216026). CRD received support from the Brazilian Conselho Nacional de Desenvolvimento Científico e Tecnológico (CNPq) (306527/ 2016-2), Coordenação de Aperfeiçoamento de Pessoal de Nível Superior (CAPES) (AUXPE 2306/2018), and Fundação Carlos Chagas Filho de Amparo à Pesquisa do Estado do Rio de Janeiro (FAPERJ) (E-26/203.038/2017). ARVS was recipient of a fellowship from CAPES. AN and AB received support from the German Ministry of Health.

\section{Availability of data and materials}

The datasets generated and/or analyzed during the current study are available in the Genbank accession numbers VK01 (BK013339), VK02 (BK013340), VK05 (BK013341), VK08 (BK013342), VK12 (BK013343), camelpox virus strain CMS (AY009089), variola virus strain Bgd75 (DQ437581), cowpox virus strains GRI90 (X94355), BriRed (AF482758), Aust1999 (HQ407377.1), HumBer07/1 (KC813509.1), GER90 (HQ420896), monkeypox virus strain DRC 07-0662 (JX878429), vaccinia virus strain Mulford 1902 (MF477237), horsepox virus strain MNR76 (DQ792504); vaccinia virus strains: WR (AY243312), Copenhagen (M35027), LC16m8 (AY678275), Serro 2 (KF179385), Cantagalo isolate CM-01 (KT013210), IHDW (KJ125439), Lister 107 (DQ121394), Dryvax clones DPP10 (JN654977), DPP11 (JN654978), DPP15 (JN654981), DPP20 (JN654985), DPP13 (JN654980), DPP21 (JN654986), DPP25 (KJ125438), ACAM2000 (AY313847), Tiantan clones TT8 (JX489135), TT5 (KC207811), Ectromelia virus strain Moscow (AF012825.2), Tashkent clones TKT3 (KM044309), and TKT4 (KM044310). Complete sequencing data are available through the SRA accession PRJNA561155.

\section{Competing interests}

The authors declare that they have no competing interests.

\section{Author details}

${ }^{1}$ Centre for Biological Threats and Special Pathogens 1 - Highly Pathogenic Viruses \& German Consultant Laboratory for Poxviruses \& WHO Collaborating Centre for Emerging Infections and Biological Threats, Robert Koch Institute, Berlin, Germany. ${ }^{2}$ Instituto de Biofísica Carlos Chagas Filho, Universidade Federal do Rio de Janeiro, Av. Carlos Chagas Filho, 373 - CCS, Ilha do Fundão, Rio de Janeiro, RJ 21941-590, Brazil. ${ }^{3}$ Institute of Human Virology, University of Maryland School of Medicine, Baltimore, MD, USA.

Received: 10 August 2020 Accepted: 11 November 2020

Published online: 04 December 2020

\section{References}

1. Esparza J, Schrick L, Damaso CR, Nitsche A. Equination (inoculation of horsepox): an early alternative to vaccination (inoculation of cowpox) and the potential role of horsepox virus in the origin of the smallpox vaccine. Vaccine. 2017;35:7222-30.

2. Damaso CR. Revisiting Jenner's mysteries, the role of the Beaugency lymph in the evolutionary path of ancient smallpox vaccines. Lancet Infect Dis. 2018;18:e55-63.

3. Esparza J, Nitsche A, Damaso CR. Beyond the myths: novel findings for old paradigms in the history of the smallpox vaccine. PLoS Pathog. 2018;14:e1007082.

4. Schrick L, Tausch SH, Dabrowski PW, Damaso CR, Esparza J, Nitsche A. An early American smallpox vaccine based on horsepox. N Engl J Med. 2017;377:1491-2.

5. Tulman ER, Delhon G, Afonso CL, Lu Z, Zsak L, Sandybaev NT, Kerembekova UZ, Zaitsev VL, Kutish GF, Rock DL. Genome of horsepox virus. J Virol. 2006;80:9244-58.

6. Medaglia ML, Moussatche N, Nitsche A, Dabrowski PW, Li Y, Damon IK, Lucas CG, Arruda LB, Damaso CR. Genomic analysis, phenotype, and virulence of the historical Brazilian smallpox vaccine strain IOC: implications for the origins and evolutionary relationships of vaccinia virus. J Virol. 2015;89:11909-25.

7. Duggan AT, Klunk J, Porter AF, Dhody AN, Hicks R, Smith GL, Humphreys M, McCollum AM, Davidson WB, Wilkins K, et al. The origins and genomic diversity of American Civil War Era smallpox vaccine strains. Genome Biol. 2020;21:175.

8. Bolger AM, Lohse M, Usadel B. Trimmomatic: a flexible trimmer for Illumina sequence data. Bioinformatics. 2014;30:2114-20.

9. Bankevich A, Nurk S, Antipov D, Gurevich AA, Dvorkin M, Kulikov AS, Lesin VM, Nikolenko SI, Pham S, Prjibelski AD, et al. SPAdes: a new genome assembly algorithm and its applications to single-cell sequencing. J Comput Biol. 2012;19:455-77.

10. Tcherepanov V, Ehlers A, Upton C. Genome Annotation Transfer Utility (GATU): rapid annotation of viral genomes using a closely related reference genome. BMC Genomics. 2006;7:150. 
11. Katoh $\mathrm{K}$, Standley DM. MAFFT multiple sequence alignment software version 7: improvements in performance and usability. Mol Biol Evol. 2013;30:772-80.

12. Tamura K, Stecher G, Peterson D, Filipski A, Kumar S. MEGA6: molecular evolutionary genetics analysis version 6.0. Mol Biol Evol. 2013; 30:2725-9.

13. Noyce RS, Lederman $\mathrm{S}$, Evans $\mathrm{DH}$. Construction of an infectious horsepox virus vaccine from chemically synthesized DNA fragments. PLoS One. 2018;13:e0188453.

14. Esparza J, Lederman S, Nitsche A, Damaso CR. Early smallpox vaccine manufacturing in the United States: introduction of the "animal vaccine" in 1870, establishment of "vaccine farms", and the beginnings of the vaccine industry. Vaccine. 2020;38:4773-9.

\section{Publisher's Note}

Springer Nature remains neutral with regard to jurisdictional claims in published maps and institutional affiliations.

Ready to submit your research? Choose BMC and benefit from:
- fast, convenient online submission
- thorough peer review by experienced researchers in your field
- rapid publication on acceptance
- support for research data, including large and complex data types
- gold Open Access which fosters wider collaboration and increased citations
- maximum visibility for your research: over 100M website views per year
At BMC, research is always in progress.
Learn more biomedcentral.com/submissions

